\title{
Культурная составляющая учебников иностранных языков
}

\author{
Юлия Михайлова \\ (Муниципальный университет г. Хиросима)
}

\begin{abstract}
Вступление
Неоспоримо, что учебники играют большую роль в обучении иностранным языкам, хотя в последнее время их стал заменять интернет. В принципе, обучение иностранным языкам включает четыре основных компонента: способность слышать и понимать язык, читать, писать и говорить на нем. Однако с конца 20-го века, когда глобализация сделала межкультурное общение повсеместным, педагоги и исследователи стали все более придерживаться точки зрения о том, что культура является таким же неотъемлемым компонентом изучения иностранных языков, как и сам язык, и заговорили о культурной составляющей учебников (Андронкина, 2001; Curdt-Christiansen \& Weninger, 2018).

В прикладной лингвистике пока еще существует не так много исследований на тему, что и как выбирать в качестве культурного компонента учебника. Ученые, стоящие на позициях модернизма полагают, что нужно давать объективные факты о стране изучаемого языка. Другие придерживаются постмодернистской трактовки, согласно которой культура не существует сама по себе, а является такой, какой ее видит автор учебника (Risager \& Chapelle, 2013, p. 1620-1625). Многие считают, что учебники иностранных языков могут в равной мере использовать примеры не только из культуры страны изучаемого языка, но и из своей собственной, хорошо знакомой учащимся (Hardy, 2004). На наш взгляд, в культурную составляющую должно быть включено и то, как та или иная страна позиционирует себя в отношениях с другими странами.
\end{abstract}


Проделанные исследования указывают на наличие различных способов репрезентации культуры, на идеологические характеристики средств, избираемых авторами, а также на множественность методов выявления культурной составляющей. Они могут включать количественный подсчет слов и тем, взятых из большого объема текстов, ориентироваться на критический анализ выбранных отрывков из учебника как «продукта», встроенного в более широкий институциональный, культурный и политический контексты, и даже на субъективные впечатления от чтения учебников (Risager, 2014; Sandorova, 2014).

Настоящая статья ставит своей задачей проанализировать культурную составляющую прежде всего «Учебника японского языка», созданного преподавательским коллективом Московского Государственного Университета под руководством профессора И. В. Головнина в 1971-1973 гг. Этот учебник сопоставляется с вышедшем почти в то же время в Японии учебником японского языка под названием «Japanese for Today» (Японский язык сегодня) (Yoshida, 1973). Последний также появился в результате коллективного творчества группы преподавателей района Кансай, которую возглавил профессор Ёсида Ясуо, и мгновенно стал популярным во всем мире. Советский учебник состоит из 40 уроков, а выпущенный в Японии из 30 , то есть они примерно одинаковы по объему материала. Кроме того, для сравнения будет использовано пост-советское издание «Учебника японского языка» под редакцией И. В. Головина (Учебник..., 2009). В 2003 г. Ученый совет Института стран Азии и Африки при МГУ признал этот учебник классическим, поскольку его «авторы не только создали на русском языке концепцию научного описания японского языка, но и разработали соответствующую методику преподавания этой дисциплины в высшей школе» (Маевский, 2003, с. 5). В связи с этим учебник уже трижды переиздавался в пост-советское время. При анализе учебников мы в основном руководствовались анализом содержания их текстов в контексте времени и идеологии, хотя, насколько это позволяют рамки статьи, в отдельных случаях приводится конкретная лексика, использующаяся в уроках.

Кто-то может подумать, что нет большого смысла обращаться к учебнику, созданному в Советском Союзе почти полвека назад, когда заведомо известно, что во времена «холодной войны» все гуманитарные публикации подчинялись идеологическим задачам. Однако нам кажется важным по- 
казать, что даже в то время, когда Советский Союз и Япония находились в разных идеологических лагерях, авторы учебника старались сбалансировать между необходимой для того времени идеологией (иначе бы учебник просто не вышел!) и вместе с тем показать, что Япония и Россия имели точки соприкосновения, особенно на межличностном уровне.

При анализе культурной составляющей учебников мы постараемся выявить тот «образ Японии», который создавался в каждом из них. Таким образом, будет показано, что культурный компонент в учебниках иностранного языка зависит от разнообразных факторов, начиная с общей обстановки в мире, состояния отношений между странами до личных пристрастий авторов и их представлений о том, что необходимо дать учащимся в тот или иной исторический момент.

\section{Советско-японские отношения после Второй мировой войны}

В условиях «холодной войны» и идеологических противоречий между бывшими союзниками урегулирование советско-японских отношений проходило с большим трудом. На Сан-Францисской мирной конференции (1951 г.) советская сторона всячески демонстрировала свое несогласие со стремлением США использовать договор для сохранения своей гегемонии в Тихоокеанском регионе, в том числе и в Японии, но предложения СССР по внесению в договор положений о нейтралитете Японии были проигнорированы. Москва также не имела надежных шансов на юридическое оформление своих прав на присоединение Курил, поскольку американский проект договора не предусматривал указание на страну, в пользу которой Япония отказывалась от юридического титула на острова (Чугров, 2015, c. 629-630). В знак протеста Советский Союз не подписал мирный договор.

Ситуация несколько изменилась, когда в конце 1954 г. премьер-министром Японии стал И. Хатояма, который был увлечен идеей нормализации отношений с Советским Союзом и стремился к продвижению японских интересов посредством торговли. Проходившие в 1955-1956 гг. советскояпонские переговоры подробно описаны в научной литературе, поэтому ограничимся лишь констатацией того, чем они завершились. Обе стороны уже были готовы подписать договор на условиях передачи Японии острова Шикотан и архипелага Хабомаи в обмен на подписание мирного договора (Чугров, 2015, с. 636), но произошло вмешательство США, заявивших, 
что если Япония подпишет договор на таких условиях, то США оставят за собой Окинаву. В результате Советский Союз и Япония подписали лишь Совместную декларацию, согласно которой дипломатические отношения восстанавливались, но без подписания мирного договора. С тех пор концепция «четырех островов» стала тем «клином», который был вбит между Советским Союзом и Японией логикой «холодной войны» (Хара, 2013, с. 147).

Тем не менее, несмотря на наличие разногласий по территориальной проблеме в 1960-х гг. стала наблюдаться тенденция к поступательному развитию советско-японских экономических связей, доказательством чему было проведение двух советских торгово-промышленных выставок в Токио и усиление интереса к Советскому Союзу со стороны японских деловых кругов. В каждой из стран были учреждены комитеты по экономическому сотрудничеству, обсуждались проекты по освоению природных ресурсов Сибири и Дальнего Востока, в которых была заинтересована набиравшая быстрые темпы развития японская экономика. Были подписаны соглашения о научно-техническом сотрудничестве и о воздушном сообщении между Японией и СССР, начался научный и гуманитарный обмен. В такой обстановке создание нового учебника японского языка, который пришел бы на смену учебникам военного времени, стало насущной необходимостью.

В Советском Союзе менялось и отношение к изучению иностранных языков в целом. На смену традиционному грамматико-переводному методу пришел коммуникативный метод, основная цель которого состояла в том, чтобы научить человека общаться, сделав так, чтобы его речь была понятна собеседнику. Конечно, все учебные материалы по-прежнему должны были проходить через множество идеологических фильтров, так как советские руководители опасались, что изучение иностранных языков будет подспудно оказывать «негативное» влияние на учеников. Как заметила М. Л. Майофис, иностранному языку нужно было обучать так, чтобы его изучение «не сопутствовало усвоению чуждых ценностей, мировоззрения, культуры. ....Сам иностранный язык и связанные с ним национальные культуры...переводились на 'советский язык', редактировались, адаптировались» (Майофис, 2016, с. 306). И все же изучая, например, английский язык, невозможно было избежать притяжения культуры англоязычных стран, например, музыкальных групп Beatles или Rolling Stones. После 
Олимпийских игр в Токио в 1964 г. и завоевания чемпионского титула японской женской командой по волейболу в Советском Союзе во всю заговорили о Японии, об уникальности ее эстетической традиции, развитых технологиях и отличной системе менеджмента. Двойственное отношение ко всему иностранному хорошо просматривается и в «Учебнике японского языка» под редакцией И. В. Головнина.

При оценке содержания учебника следует учитывать, что сам Головнин начал изучать японский на курсах военных переводчиков при штабе Тихоокеанского флота во Владивостоке в 1943-1945 гг. Потом он стал слушателем в Военном институте иностранных языков в Москве, где японскую кафедру возглавлял Н. И. Конрад, бывший уже тогда известным ученым. С августа 1945 г. по октябрь 1947 г. Головнин служил в рядах Советской Армии в качестве переводчика. Потом закончил аспирантуру Военного института иностранных языков, преподавал японский сначала в том же институте, а в впоследствии стал профессором кафедры японской филологии ИСАА МГУ. Именно ему как «надежному и проверенному товарищу» и было поручено составление учебника, первого и вплоть до перестройки чуть ли не единственного, полноценного учебника японского языка. Вместе с тем, в состав авторов учебника входил Л. А. Стрижак, являвшийся репатриантом из Маньчжурии, который часто работал в качестве переводчика при советских делегациях, направлявшихся в Японию.

\section{Принципы построения учебника}

Учебник Головина состоял из трех книг: Книга первая — для начинающих; книга вторая (часть I) и книга третья (часть II) — для продолжающих. Типовая структура урока имела следующие разделы. В книге первой шесть уроков посвящались фонетике и письменности (обучение письму продолжалось и дальше), потом шла грамматика, затем следовала лексикология и три текста. Текст 1-й давал грамматические модели. Текст 2-й содержал рассказ на главную тему урока, где вводилась новая лексика, а в тексте 3-м та же тема разрабатывалась на примере диалогов. Отдельно следовал словарь новых слов, затем шли обиходные, часто идиоматические, выражения, не связанные с основным текстом и диалогами. Введенные новые слова и выражения объяснялись дополнительно в комментариях. Разнообразные упражнения представляли из себя перевод с японского на русский и наоборот. 
Культурная составляющаяучебников иностранных языков

Другими словами, эта система обучения японскому языку состояла из традиционно принятых компонентов - чтения и понимания текстов, умения говорить и воспринимать на слух, а также писать по-японски. Кроме того, обучающие усваивали структуру и логику японского языка, должны были быть в состоянии соотнести его с русским, понимать, в чем их сходство и различие. Новый материал прорабатывался, повторялся и уточнялся различными способами.

Такой авторитет в области японской лингвистики как В. М. Алпатов считает, что период 1960-1970-х гг. был «периодом достижений» в изучении и преподавании японского языка в России потому, что в «нашем японоведном языкознании все больше начали переходить от идей русистики к идеям общего языкознания, от стремления втиснуть японский язык в рамки привычных категорий к выявлению специфики данного языка» (Алпатов, 2015, с. 27). Среди ученых, удостоившихся высокой оценки, Алпатов назвал имена И. В. Головнина и А. А. Пашковского, оба из которых входили в авторский коллектив рассматриваемого учебника. Авторов учебника можно упрекнуть в излишней детализации объяснения грамматики, в перегруженности малоупотребительными моделями, в некоторой «сухости» стиля изложения по сравнению с зарубежными учебниками того времени, в отсутствии игровых упражнений, но с задачей заложить у учащихся хорошую основу японского языка учебник вполне справлялся.

В предисловии к книге первой говорится, что «тексты учебника составлены на материале советской действительности потому, что подавляющему большинству учащихся приходится применять японский язык в общении с японцами, приезжающими в Советский Союз (Головнин, 1971, с. 4). Действительно, в 1960-1970-е годы попасть в Японию обыкновенному советскому человеку было почти невозможно. Помимо сотрудников дипломатических и торговых миссий, в Японии работали корреспонденты газет, радио и ТАСС. Туда ездили члены профсоюзных организаций, небольшое число научных сотрудников, деятелей культуры и искусства. Однако из Японии в Советский Союз уже стали приезжать не только делегации профсоюзов, но и просто группы туристов. В этом смысле ориентация авторов учебника кажется вполне объяснимой. В сущности он готовил экскурсоводов, обладающих прочным знанием японского языка, которые были бы в состоянии рассказать о своей стране «идеологически выдержанно» и имели бы базовые представления о Японии. 
Авторы учебника японского учебника «Japanese for Today» ставили перед собой другую задачу, а именно, использовать живой японский язык в типовых ситуациях, чтобы помочь учащимся понять современную Японию, выходя тем самым за рамки обучения языку (Yoshida, 1973, p. 1). Они стремились добиться того, чтобы иностранные учащиеся могли осмысленно участвовать в жизни японского общества, находясь в этой стране. Один из приемов, использовавшихся ими, состоял в том, чтобы сначала дать прослушать записанный на пленку главный текст урока по-японски, а затем его же можно было прочитать в транскрипции ромадзи. Тем самым облегчалось запоминание типовых фраз, но без глубокого знания грамматики. Грамматические объяснения хотя и были составной частью урока, но скорее исходили из потребностей текста, чем основывались на определенной системе и методике преподавания.

\section{Тематическое содержание уроков в советском учебнике}

Именно тематическое содержание текстов дает наилучшее представление о культурной составляющей учебников. В советском учебнике первый текст «Наша аудитория» появляется в седьмом уроке (до этого были только отдельные слова и предложения), урок восьмой предлагает описание по картинкам «Дня студента», девятый - комнаты, где студент живет, десятый вводил тему «Моя семья», одиннадцатый и двенадцатый посвящены рассказу о студенческой жизни.

Bсе эти темы близки и легко понятны студентам и вполне логично считать, что их лексика должна была быть освоена в первую очередь. Она включала обычные предметы, находящиеся в учебных помещениях и в комнате для проживания в общежитии. Семья, описанная в тексте, состояла из родителей, братьев и сестер. Отец сначала был рабочим на автомобильном заводе, потом окончил вечерний техникум, и стал инженером. Мать преподавала в школе английский язык, а старшая сестра русский язык. Другие сестры и братья учились либо в техникуме, либо в школе. В общем, это была «типичная советская семья».

Несколько неожиданным был внезапный переход от такой обыденной тематики к теме празднования юбилея Октябрьской социалистической революции, которая, как известно, была главным постулатом советского идеологического канона, и избежать какого-либо упоминания о ней 
в то время было практически невозможно. На этой теме учебник для начинающих и заканчивался. В учебнике повествование о революции дается через пересказ фильма на соответствующую тему.

Как явствует из пересказа, сначала якобы показывалась жизнь рабочих и крестьян до революции. Затем следовали сцены самой революции и самоотверженного труда рабочих, направленного на развитие промышленности: «Рабочие трудились допоздна, не зная сна. Производство возросло и жить стало хорошо... Однако в 1941 г. началась война. Сплотившись, народ боролся с фашизмом... и победил в войне. Когда наступил мир, строительство социализма продолжилось. Во всех странах развернулось движение за мир» (Головнин, 1971, с. 248-249). Именно такими или примерно такими словами все, изучавшие иностранные языки, должны были уметь рассказать об истории своей страны иностранцам. «Рабочие», «крестьяне», «народ», «эксплуатация», «революция», «социализм», «фашизм», «труд», «война», «мир», «съезд» - вот главные слова, которые вводились в лексикон изучавших японский язык в связи с темой Октябрьской революции (Головнин, 1971, c. 251-152).

Вторая книга учебника, то есть часть 1 (для продолжающих), начинается с объяснения грамматических конструкций, выражающих намерение. Эта тема раскрывается на примере текста о пользовании японцами городского транспорта в Москве, желания приобрести альбом фотографий города или сделать их самостоятельно. Жители советской столицы охотно помогают приезжим, объясняя дорогу, провожая их до метро или книжного магазина. В словаре этого урока фигурируют слова «гостиница», «осматривать», «проспект», «фотография», «превосходный», «красивый», «электричка», «троллейбус», «площадь», «книжный магазин», «метро», «эскалатор», «деньги», «быть внимательным» и другие, связанные с передвижением по городу и в то же время передающие восхищение Москвой японцами (Головнин, 1973, ч. 1, с. 18).

Второй урок вводит конструкции, выражающие сравнение, и здесь довольно удачно говорится о климате и погоде в Японии и России. Среди вводимой лексики появляются следующие слова: «климат», «сакура», «север», «юг», «земля», «ветер», «одинаковый», «туча», «дождь», «облака», «молния», «гром», «прогноз погоды», «красный клен», «срана» и другие, соответствующие теме урока (Головнин, 1973, ч. 1, с. 36). 
В третьем уроке появляется тема путешествия по Японии, а именно воспоминания о поездке на поезде «Цубамэ» по линии Токайдо из Токио в Осаку, которая тематически как нельзя лучше подходит для учебника японского языка. Правда, несколько досадно, что авторы взяли для примера поезд «Цубамэ», а не появившийся во время Олимпийских игр 1964 г. супер-экспресс Синкансэн. Правда, это может свидетельствовать о том, что на создание учебника ушел не один год и за это время транспортные средства изменились. Лексика учащихся пополняется словами «поезд», «платформа», «пассажир», «провожать», «багаж», «экспресс», «отправление», «вагон-ресторан», «промышленный район», «кондуктор», «локомотив», «развитие», «знаменитый», «пейзаж», «залив», «озеро», «столица», «буддийский храм», «население», «город», «путешествие».

Урок четвертый переносит нас обратно из Японии в Москву. В нем говорится о том, как автор вместе с группой колхозной молодежи («ватаситати-но корухо:дзу-но сэйнэнтати») ездил с экскурсией по Москве (Там же, с. 63). С не меньшим успехом можно было бы рассказать об осмотре Москвы японцами, но упоминание о «колхозной молодежи», видимо, понадобилось для того, чтобы показать, что все слои советского общества имели возможность общаться с иностранцами. В диалоге того же урока, уже побывавший на экскурсии японец рассказывает другому о достопримечательностях Москвы. Как и следовало бы ожидать от советского учебника, во время экскурсии много внимания уделяется достопримечательностям, связанным с революцией, и дело не обходится без упоминания о Дворце Съездов и принятой там новой программе партии. В лексике урока фигурируют следующие слова: «путеводитель», «объяснение», «памятник», «музей», «ученый», «учреждать», «выставочный зал», «витрина», «магазин», «советский», «поражаться», «скульптура», «набережная», «холм», «замечательный», «дворец», «башня», «актовый зал». Среди собственных имен и названий много слов, тоже связанных с советской тематикой: Карл Маркс, Свердлов, Дом Союзов, Дворец Съездов, а исторические названия, такие как Кремль, Красная площадь, мавзолей В. И. Ленина ассоциируются прежде всего с советским периодом истории.

В пятом уроке дается тема «Олимпийские игры», поданная культурно и политически нейтрально. Внимание сосредотачивается на азарте и удовлетворении, получаемыми спортсменами при достижении успеха, 
а в лексике фигурируют термины, связанные со спортом: «спортсмен», «легкая атлетика», «спортивный коллектив», «рекорд», «терпеть поражение», «ловкий», «успешный», «справедливый», «приятный», «международный», «важный». В шестом уроке с юмором рассказывается об обеде в вагоне-ресторане одного любителя поесть. Исходя из того, что в тексте упоминаются красная икра и черный хлеб, явствует, что действие происходит в России, хотя национальность «обжоры» остается не раскрытой. Урок не только вводит лексику, связанную с едой («завтрак», «толстеть», «проголодаться», «обед», «аппетит», «официант», «кофе», «икра», «бутерброд», «готовить пищу», «мясо», «овощи», «посуда» «меню», «салат», «суп», «рыба», «горчица», «перец», «масло», «хлеб»), но и передает приятные и не очень приятные вкусовые ощущения, получаемые от пищи: «сладкий», «вкусный», «соленый», «кислый», «острый», «странный».

Урок седьмой - единственный в советском учебнике текст, где фигурируют женщины. Это жены японцев, проживающих в Советском Союзе, и в уроке говорится о центре бытового обслуживания, который значительно облегчал повседневную жизнь в СССР. Заметим, что японские женщины представлены в типичной для Японии того времени роли домохозяек, тогда как советские женщины в учебнике вообще не появляются, хотя в другом уроке дается упоминание о том, что они составляли $20 \%$ работающих на заводах (Головнин, там же, с. 165). Приведем слова, вводимые в данном уроке: «комбинат бытового обслуживания», «предметы повседневного обихода», «быть запачканным», «изнашиваться», «надевать одежду», «надевать обувь», «ломаться», «стирка», «домашнее хозяйство», «уборка», «ремонт», «утюг», «химчистка», «красить», «бельё», «приемный пункт», «дыра», «пятно», «гарантия», «бесплатный», «удобный», «принимать», «квитанция». Через эти слова создается впечатление, что японцы привыкли жить скромно и бережливо.

В тексте восьмого урока говорится о системе государственного устройства Советского Союза и о выборах в органы власти. Рассказ ведется от лица молодого человека, который впервые участвует в выборах. В частности, мы читаем: «Верховный Совет, избирается всеми людьми, которые имеют право участия в выборах. Также местные советы депутатов трудящихся, которые являются органами власти на местах, избираются всеми людьми, проживающими в данной местности. Выборы проходят при тайном голо- 
совании без указания имен» (Головин, там же, с. 135). Текст предназначен для демонстрации идей равенства и демократии в их советском варианте, но он скрывает тот факт, что в сущности выборы в советы носили чисто формальный характер и являлись хорошо отрепетированной «показухой». Тем не менее это не становится очевидным из приведенных слов в словаре данного урока: «республика», «государство», «механизм», «избирательное право», «собрание», «выборы», «голосование», «доверять», «население», «представитель», «бюллетень для голосования», «трудящийся», «интересы», «национальность», «равноправие», «дискриминация», «конституция», «запрещать», «власть», «тайное голосование», «правительство», «старание», «делегат», «работа».

После этого идеологически насыщенного текста приятное впечатление производит тема «В универсальном магазине», данная в следующем, девятом, уроке. Что же могло привлечь японцев в советских магазинах 1970-х гг.? Авторы придумали остроумный ход, рассказав, что японцы любили наведываться в отдел головных уборов, где с удовольствием покупали меховые шапки. Меховая шапка была в Японии одним из символов России, начиная с русско-японской войны, ведь нечто похожее носили казаки. Она также ассоциировалась с холодными русскими зимами, но здесь главными носителями информации скорее были военнопленные. Вместе с тем, надевая меховую шапку, японцы погружались в мир русской экзотики, и через этот игровой прием происходило как бы сближение партнеров. В начале 1970-х гг. в Японии стала расцветать страсть к потреблению товаров. С другой стороны, полки советских магазинов, по крайней мере в Москве, еще не были пустыми. Авторы советского учебника имели основание написать тогда: «В СССР все работают, а товары недорогие». В ГУМе японцы покупали не только шапки, но и перчатки, брюки, фотопленки и продукты. Словарь вводит следующие слова: «универмаг», «покупки», «продавать», «прилавок», «газированная вода», «пальто», «консервы», «продукты», «продавец», «взвешивать», «колбаса», «товар», «расчет», «цена», «шапка», «зеркало», «размер», «перчатки», «брюки», «быть к лицу», «подходить», «фотопленка», «подарки», «фонтан», «голова», «спешить» (Головин, там же, с. 156).

Весьма показательным с точки зрения культурной составляющей учебника является урок десятый, который содержит текст «Письмо рабочего», 
повествующий о «весенней борьбе» японских трудящихся. Так назывались переговоры между трудовыми профсоюзами и компаниями о повышении заработной платы и улучшении условий труда. Хотя автор письма жалуется, что «среди капиталистов есть такие, которые заставляют нас работать без отдыха в плохих условиях», как правило, японским рабочим и предпринимателям удавалось найти общий язык и определить взаимоприемлемый уровень повышения заработной платы. «Весенняя борьба» вносила значительный вклад в повышение уровня жизни всего работающего населения Японии (Минагава). Пик борьбы пришелся на период нефтяного кризиса 1970-х гг. После этого забастовки пошли на убыль и практически исчезли в годы экономики «мыльного пузыря». В этом уроке объяснялось повелительное наклонение, и фразы типа «Накама-о куби-ни сасэруна!» (Не допустим увольнения рабочих!) или «Тингин-о агэро!» (Поднять зарплату!) хорошо вписывались в качестве примеров для объяснения грамматики. Кроме того, в словарь были включены термины, чтение которых дает хорошее представление о содержании урока: «посещение больного», «больница», «сельская местность», «лекарство», «беспокойство», «зарплата», «врач», «угольная шахта», «условия труда», «безопасность», «сплочение», «забастовка», «требование», «коллектив», «переговоры», «быть стойким», «увольнять с работы», «безработица», «расходы на жизнь», «уровень», «экономика», «политика», «выступать против», «обратить внимание», «компания», «пикет», «шпион», «подготовка», «впереди», «свободное время» (Головин, там же, с. 169).

Основной текст урока одиннадцатого рассказывает о кемпинге советских студентов, а в тексте с диалогами говорится об аналогичном времяпрепровождении молодых японцев. Здесь используется известный культурологический прием, позволяющий выразить идею схожести и равенства двух стран и народов.

Урок двенадцатый рассказывает о праздновании Первого Мая в Советском Союзе, празднике, который в 1970-е годы еще не утратил своей привлекательности для жителей этой страны. В диалоге, следующем за основным текстом, представлен разговор между японцем и русским, по-видимому, созерцающими колонны демонстрантов где-то с трибуны на Красной площади. Обращает на себя внимание следующая фраза японца: «Я слышал по радио, что хотя в Токио идет дождь, несколько сот тысяч человек 
участвовали [в демонстрации]» (Головин, там же, с. 204). Эта фраза могла и не соответствовать действительности, так как закон 1948 г. о Национальных праздниках в Японии не включал 1-е Мая в качестве праздника. Однако авторы учебника мыслили советскими категориями. В словаре мы находим следующие слова: «радиостанция», «репортаж», «демонстрация», «солидарность», «транспарант», «здоровье», «счастье»», «защитник», «класс», «империализм», «обеспечивать», «праздник», «пионер».

Последний урок части 1 (для продолжающих) называется «Почта» и содержит полезную деловую информацию о пользовании почтой и видах почтовых отправлений из СССР в Японию.

Первые два текста части 2 (для продолжающих) «Гостиница» и «Музей изобразительных искусств им. Пушкина» однозначно составлены в помощь экскурсоводам. Они несут сведения о том, как оформлять документы для проживания в гостинице, как пользоваться имеющимися там службами и дают краткие сведения о составе коллекций музея. Третий урок о «Литературных связях между Советским Союзом и Японией» содержит более глубокие, хотя и довольно известные рассуждения, о значении культурного обмена для взаимопонимания между народами. Отрадно, что в этом уроке говорится не только о влиянии русской литературы на Японию, но подчеркивается и интерес к современной и классической японской литературе в Советском Союзе. Следующий, четвертый урок под названием «Путешествие по воздуху» повествует о том, как развитие самолетостроения облегчило поездки между Японией и Советским Союзом и сделало длительный по времени перелет приятным. Этот текст не только повествует об успехах экономического развития Советского Союза, но, как и предыдущий, направлен на то, чтобы подчеркнуть возможности для развития советско-японских связей.

Хотя в предисловии к учебнику говорилось о том, что тексты направлены в основном на помощь учащимся, имеющим дело с японцами, приезжающими в Советский Союз, несколько уроков знакомят студентов с самой Японией и включают рассказ о приезде в Японию советского студента. Весьма информативен текст урока пятого о сельском хозяйстве Японии, где подробно объясняется его послевоенное развитие, в частности, процесс механизации и использования химических удобрений, перепрофилирование многих районов Японии на выращивание овощей. В заключение 
выдвигается тезис о том, что природные условия и рост населения вряд ли позволят японцам в ближайшем будущем обеспечивать себя рисом, что соответствовало действительности (Головнин, там же, с. 74-82).

В учебнике имеется текст о географии Японии, который включает не только информацию о природных условиях, погоде и административном делении, но повествует также об успехах экономики страны, подчеркивая, что «в настоящее время Япония стала одной из наиболее развитых промышленных стран мира». Как и следовало ожидать, советский учебник никак не затрагивал территориальный вопрос, а лишь упоминал, что в Японии имеется около трехсот островов (Головнин, там же, с. 148).

По крайней мере два текста учебника, можно сказать, проникнуты какой-то особой теплотой к Японии. Прежде всего это текст с письмом японского мальчика своему советскому другу, в котором рассказывается о традиционных японских обычаях - праздновании Нового года, Празднике девочек и Празднике мальчиков. В диалоге, сопровождающем этот текст, друг из Советского Союза уже сам приезжает в Японию и празднует Новый год в японской семье, обмениваясь подарками по японским обычаям.

Другой текст «Зоопарк» дает еще одну зарисовку из повседневной жизни японской семьи, рассказывая о том, как старший брат повел двух младших в зоопарк. Здесь с юмором говорится о любознательности и шаловливости младших детей и о напускной серьезности старшего брата. В целом создается картина того, что японские дети ничем не отличаются от своих советских сверстников.

Остальные тексты на более высоком грамматическом, синтаксическом и лексическом уровне вновь освещают тему Октябрьской революции, повествуют о посещении японской делегацией машиностроительного завода, что обычно входило в программу пребывания делегаций в СССР, и о вечере искусств народов СССР во Дворце Съездов. Текст последнего урока учебника называется «О мирном сосуществовании» и выглядит словно передовая из газеты «Правда» или отрывок из речи Н. С. Хрущева на XXII съезде КПСС (1961 г.). Из истории известно, что до того, как СССР и США не достигли ядерного паритете и не подписали Договоры ОСВ-1 (Ограничение Стратегических Вооружений, 1972 г.) и ОСВ-2 (1979 г.), «мирное сосуществование» проявлялось скорее только в риторике, а в дей- 
ствительности отношения Советского Союза с капиталистическими странами не шли дальше ознакомительных обменов делегациями, о которых так много было написано в учебнике под редакцией Головина. Соответственно, в словаре урока доминирует политическая лексика, часть которой мы приведем: «сосуществование», «воззвание», «принцип», «внешняя политика», «агрессия», «отпор», «атмосфера», «ядерный», «запрещение», «договор», «ужасный», «термоядерная война», «общедемократический», «земной шар», «конфликты», «переговоры», «невмешательство», «гонка вооружений».

В одном из уроков японские деятели культуры делились своими впечатлениями от поездки по Советскому Союзу. Разумеется, какие-либо критические высказывания здесь полностью отсутствовали, акцент делался на успехах в промышленном развитии СССР, системе образования и стойкости ленинградцев во время блокады. В Японии существовало и существует немало почитателей русской культуры, но восхищение собственной страной, вложенное в уста японцев, создавало у студентов односторонние представления об отношении жителей Страны восходящего солнца к ее северному соседу, что, в принципе, и было одной из задач советского учебника.

\section{Тематическое содержание учебника «Japanese for Today»}

Созданный в Японии учебник «Japanese for Today» начинается, можно сказать, неожиданно: учащиеся видят сакуру как символ Японии, и первая фраза, которую они узнают, означает «Это сакура». Затем следуют короткие диалоги, которые дают несколько вариантов первого знакомства между людьми в Японии, что является полезной информацией, требующей запоминания. Второй урок состоит из диалогов, где действующие лица пытаются сориентироваться в токийском метро и на улице, что весьма важно для тех, кто впервые попал в Японию. Если в советском учебнике тексты чаще носят характер авторского рассказа, то в японском учебнике делается больший акцент на разговорную речь, что придает ему живость. Японские авторы учебника сочли необходимым ввести такие разнообразные темы как хобби, время препровождения в выходные дни, игра в теннис, путешествия и пешеходные прогулки в горы, визиты к друзьям, досуг детей, посещение врача, покупка телевизора, а грамматические объяснения 
даются как бы по ходу дела. Учебник не дает систематическое объяснение грамматики. Написанный по-английски, «Japanese for Today» нацелен был прежде всего на обучение японскому языку студентов из англоязычных стран. Однако в текстах фигурируют люди самых разных национальностей, в том числе из стран Азии. Жизненные зарисовки в основном относятся к жизни представителей среднего класса Японии. Названия текстов порой звучат весьма необычно для учебника иностранного языка, например, «Интересно!» (о поездке в Киото и Нара), «Вкусно!» (об обеде в ресторане), «Удивительно!» (о том, как много издается в Японии еженедельных журналов), «Красиво!» (в день серебряной свадьбы комната красиво украшена цветами и дочь юбиляров тоже очень красивая). Невольно это формирует образ Японии как страны, достойной восхищения.

В учебнике неоднократно затрагиваются и объясняются национальные черты характера и привычки японцев. Например, в одном из уроков упоминается, что в Японии не принято платить чаевые, в другом, что японцы не любят быть в долгу перед кем-либо, а в третьем говорится о том, что, по мнению иностранцев, японцы часто улыбаются странной улыбкой, которую иностранцам трудно понять. Дело в том, объясняют авторы, что японцы избегают напрямую говорить о чем-либо хорошо или плохо с той же ясностью, как это делают носители англоязычной культуры. Ответ японцев скорее может зависеть от ощущения, какой именно отклик ожидается от него в данном случае. А пока они это не уяснили для себя, то и появляется «странноватая улыбка» (Yoshida, 1973, p. 212-213).

С точки зрения образа Японии, показателен урок 18, где дается беседа трех людей. Один из собеседников делится с другими своими соображениями о том, как лучше написать эссе для газеты, которая проводит конкурс на тему «Японцы и японская культура». Его собеседник интересуется темой о восприятии японцами иностранной культуры. Третий же замечает, что было бы интересно знать, как иностранцы относятся к японским фильмам.

В данном и в других уроках видны проявления существовавшего в 1970-е гг. так называемого бума «теорий о японцах и японской культуре». Авторы многих книг, появившихся в рамках этого жанра, были склонны объяснять успехи промышленного развития страны особенностями менталитета и психологии японцев. 
Однако диалоги и короткие словесные зарисовки, сделанные весьма мастерски, дают учащимся возможность буквально «почувствовать», как происходило становление современного японского общества, показывают, что это был сложный психологический процесс, который сопровождался работой на износ и переменами в человеческих взаимоотношениях, потерей связей со своей «малой родиной» и одиночеством в больших городах. В японском учебнике не говорится о забастовках, но дается понять, что успехи страны дались людям (можно сказать «трудящимся людям») с трудом. Именно это «напряжение сил» и дало возможность Японии стать в 1970-е гг. третьей экономической державой мира.

Помимо упомянутых выше диалогов и мимолетных зарисовок каждый урок содержит также тексты на вполне академические темы, такие как история Японии (3 текста), литература (3 текста), промышленность и экономическая жизнь (6 текстов), искусство, религия, политика - в общем, перед нами предстает чуть ли не энциклопедия Японии. Учебник почти в четыреста страниц действительно дает «панораму японской жизни».

\section{Постсоветские издания учебника И. В. Головина}

В 1999, 2003 и 2009 годах вышло, как указано на обложке, «полностью переработанное издание» «Учебника японского языка» под редакцией И. В. Головнина, хотя сам руководитель научного коллектива скончался в 1995 г. Вместо трех книг появилось четыре, хотя общий листаж уменьшился с 804 до 615 страниц. Это произошло из-за того, что было не только упрощено изложение грамматических вопросов, но также и потому, что были изъяты тексты, связанные с советской действительностью, например, посещение японской делегацией машиностроительного завода и вечер искусств народов СССР. Дать нечто аналогичное на современную тематику авторы либо не сочли уместным, либо просто не смогли проявить достаточно творчества. Исчез также и текст о литературных связях между Россией и Японией, хотя никакой идеологии в нем не было, разве что В. Г. Белинский назывался «революционным демократом». Между тем, текст о литературе заканчивался фразой: «Самая прямая дорога к миру лежит в углублении понимания между странами» (Головнин, 1973, ч. 2, с. 44).

Чисто внешне учебник тоже изменился, так как тексты, написанные ранее вертикально, стали горизонтальными, что соответствует обыден- 
ной практике составления учебников иностранных языков в современной Японии. Японские грамматические термины, дававшиеся ранее в русской транскрипции, стали теперь написаны в ромадзи.

Хорошо отражены изменения в топонимике, произошедшие в постсоветской России. Так, Ленинские горы стали Воробьевыми, Площадь Революции - Театральной, улица им. Горького - Тверской и т. п. Кампания колхозной молодежи, которая была на экскурсии в Москве превратилась в японских друзей, а внимание на экскурсиях теперь уже больше стало уделялось памятникам старины, особенно церквям, в упражнениях чаще стал упоминаться Санкт-Петербург как объект интереса японских туристов. Однако авторы учебника не ввели достаточное количество новых японских слов, которых немало появилось за прошедшие тридцать с лишним лет. В принципе в такой стране как Япония, где в конце каждого года издательства словарей объявляют списки главных новых слов, это сделать было бы не трудно, тогда как употребление вышедших из обихода старых слов, например, маннэнхииу (авторучка), просто режет глаз.

В учебнике советского периода основная культурная и идеологическая нагрузка приходилась на тексты, причем пять из них были откровенно политического содержания. В постсоветском издании тексты, являвшиеся идеологически нейтральными, например, те что повествовали о жизни студентов, об Олимпийских играх, покупках в универмаге, о вагоне-ресторане, хозяйственных заботах японских женщин и некоторые другие оставлены без всяких изменений. Тексты же, имевшие советскую идеологическую направленность, были либо упразднены совсем, либо изменены. Так, празднование Октябрьской революции превратилось в празднование двухсотлетия Великой Французской революции, что звучит несколько нелепо, поскольку в действительности такое мероприятие никогда не существовало. Вместо слов о том, какие блага Октябрьская революция принесла народу, в современном издании говорится, что Французскую революцию «горожане и крестьяне проиграли», но это утверждение остается без всяких пояснений. В переработанном издании репортаж о Всемирной Спартакиаде студентов заменил репортаж с Красной площади в день первого мая.

Рассказ о выборах в органы власти в СССР, существовавший в учебнике советского периода, был заменен на рассказ о системах законодательного устройства в новой России и Японии. Такое изменения тематики давало 
возможность сохранить наработанную лексику и грамматику, но никак не расширяло по существу сведения о России.

Любопытную метаморфозу претерпел урок, в котором говорилось о забастовках японских шахтеров. В нем, как и в учебнике советского периода, один рабочий пишет письмо другому, где сообщает как изменилась жизнь его семьи после закрытия угольных шахт. Сам он пристроился работать на небольшое предприятие, которое выполняет субподрядную работу. Больная жена, на оплату лекарств которой раньше не хватало денег, поправилась. Сын увлеченно занимается спортом.

Однако автор письма с гордостью и ностальгией, вспоминает прошлые времена, когда уголь считался «черным золотом» Японии, а работавшие в этой отрасли 550 тысяч шахтеров в постоянной борьбе за улучшение условий труда способствовали послевоенному возрождению и развитию страны (Учебник..., 2009, Книга 4, с. 94-95).

В диалоге того же урока другой бывший шахтер также говорит о переменах в своей жизни. «Он стал работать охранником (га:доман) большого здания, и хотя ему не доставляет большого удовольствия проверять входящих в здание людей, по сравнению с шахтой эта работа более легкая, за ночные смены идет дополнительная зарплата, а два выходных дня в неделю стали нормой жизни» (Там же, с. 96-97). Бывший шахтер также пишет о том, что благодаря рабочим японская промышленность смогла успешно развиваться, и Япония стала богатой страной. Поэтому, он выражает уверенность в том, что «наше движение не пропало даром».

Казалось бы, новое издание «Учебника японского языка» действительно «полностью переработано», однако каждый носитель русского языка почувствует в нем остатки советской риторики. Об этом говорит употребление многих слов из советского лексикона, таких как «солидарность», «парад», «горн», не говоря уже об устаревшем слове «товарищ», которое по-прежнему фигурирует повсюду в учебнике, хотя могло бы быть безболезненно заменено на нейтральное слово «друг».

К тому же в новом учебнике появилась фраза, которая, на наш взгляд, сводит на нет всю проведенную деидеологизацию. Под рубрикой, якобы взятой «из газет», написано: «В 1905 году Япония выиграла Русско-японскую войну. В 1945 году Япония проиграла и на этом закончилась Вторая мировая война» (Учебник..., 2009, Книга 2, с. 204). Здесь звучит намек 
на существование болезненной для каждой из двух стран проблемы территориального размежевания, возникшей после Второй мировой войны. Эта проблема является весьма сложной и ее исследованию посвящены десятки научных работ. Однако вышеприведенная краткая формулировка отдает «душком национализма» и является излишней в учебнике, претендующем на отсутствие всякой идеологии.

\section{Заключение}

В настоящей статье была предпринята попытка проанализировать культурную составляющую двух учебников 1970-х годов и постсоветского переиздания «Учебника японского языка». Оба учебника 1970-х гг. в большей или в меньшей степени использовали материал о своей собственной стране в качестве культурной составляющей, хотя в пяти текстах советского учебника говорилось о Японии. Каждый из этих учебников придерживался какой-либо идеологии. В учебнике, изданном под редакцией И. В. Головнина в главном ВУЗе страны, это была официальная советская идеология. В японском учебнике ею являлись популярные в то время в Японии и в мире «теории о японцах и японской культуре», поддерживавшиеся также японским правительством. Для японского учебника японского языка такая подача материала выглядела достаточно естественной потому, что культурный материал соответствовал изучаемому языку и позволял лучше понять особенности жизни страны. В советском учебнике обращение к тематике жизни в Советском Союзе, хоть и выполняло задачу обучения студентов японскому языку, в целом могло вызвать и вызывало недоумение и неприятие. Дело было не только в том, что материал был мало связан с преподаваемым в учебнике языком, мало показывал реалии японской жизни и вряд ли был по своему содержанию интересен студентам. В нем явно выступала идеологическая установка представить Советский Союз как развитую промышленную страну, борющуюся за мир, как государство демократии и равноправия, что расходилось с действительностью, и было вполне очевидно многим. Поэтому некоторые ВУЗы страны, в том числе, Кафедра японской филологии в Ленинградском государственном университете отказывались использовать учебник под редакцией И. В. Головина для преподавания.

Тем не менее, хотя количество текстов о Японии в советском учебнике было не таким большим, японскую действительность они не искажали, 
а передавали достаточно точно. Отношения между русскими и японцами рисовались дружескими и благожелательными. Особенно это чувствуется в текстах, которые повествуют о молодежи и о детях («Кемпинг», «Японские праздники. Письмо», «Зоопарк»). Тем самым как бы высказывалась надежда, что молодое поколение найдет больше возможностей для понимания друг друга. Авторы учебника не пошли по пути экзотизации Японии, которая в те годы как раз набирала силу в Советском Союзе (Овчинников, 1972). Они показали Японию как страну, успехи развития которой объяснялись трудом ее народа и его борьбой за свои права. С одной стороны, это был советский подход, но с другой - он был близок и тому, о чем говорилось в «Japanese for Today».

После распада Советского Союза оставшиеся в живых авторы «Учебника японского языка» поставили задачу переработать учебник и устранить его идеологическую составляющую, сохранив при этом наработанный грамматический и синтаксический материал. В принципе с этой задачей они справились, хотя обновление японской лексики прошло менее удачно. Вызывает сожаление, что тема о литературных связях между Россией и Японией была изъята из учебника. Вместо того, чтобы показать накопленный положительный опыт общения, авторы неосторожно задели военное прошлое.

Рассмотрение культурной составляющей учебников иностранного языка показало, что эта составляющая не является объективным фактором, а зависит от задач, которые стоят перед авторами, и соответствует довлеющему в стране и в мире идеологическому и культурному дискурсу. В наши дни учебники часто пишутся не для употребления в одной конкретной стране, а могут использоваться сразу в нескольких странах и издаваться в соответствующем переводе. Это и есть одно из проявлений глобализации, с учетом которой, вероятно, и будет развиваться содержание культурной составляющей учебников иностранных языков.

\section{ЛИТЕРАТУРА}

Алпатов В. М. Этапы изучения японского языка в России // Современное российское японоведение: оглядываясь на путь длиною в четверть века. Под. ред. Д. В. Стрельцова. - М., АИРО-ХХІ. «Ассоциация японоведов», 2015. С. 15-30.

Андронкина Н.М. Роль междисциплинарных исследований в обучении иностранному языку как специальности //Наука, культура, образование. 2001, № 8/9. С. 131-133. 
Головнин И. В., Рябкин А. Г., Лобачев Л. А. и др. Учебник японского языка (для начинающих). М.: Издательство «Высшая школа», 1971.

Головнин И. В., Рябкин А. Г., Лобачев Л. А. и др. Учебник японского языка (для продолжающих), Часть I и Часть II. М.: Издательство «Высшая школа», 1973.

Маевский $Е$. В. Предисловие к третьему изданию «Учебника японского языка» под редакцией профессора И. В. Головнина. Т. 1. М.: «Живой язык», 2003.

Майофис М. Л. Страх влияния: к краткой истории советских спецшкол (конец 1940 - начало 1960-х) // Вопросы образования, 2016, №2. С. 286-306.

Минагава X. Почему в Японии прекращаются забастовки? URL: https://www.nippon.com/ru/ currents/d10003/ (Режим доступа: 22 февраля 2019).

Овчинников Bc. Ветка сакуры: рассказ о том, что за люди японцы. М.: Молодая гвардия, 1971. Учебник японского языка. Под ред. И. В. Головнина, Кн. 1-4. М.: «Живой язык», 2009.

Чугров С.В. Отношения между СССР и Японией после войны (конец 1940-х - 1950-е годы)// Российско-японские отношения в формате параллельной истории. Коллективная монография под общ. ред. А. В. Торкунова и М. Иокибэ. М.: МГИМО-Университет, 2015.

Curdt-Christiansen X. L. and Weninger C. (eds.) Language, ideology and education: the politics of textbooks in language education. Routledge research in language education. Routledge, 2018.

Hardy T. Language and Culture: Teaching methods and materials//Teaching English Now. Vol. 6. Fall 2004. URL: https://tb.sanseido-publ.co.jp/english/newcrown/pdf/ten006/010.pdf (Accessed: 26 February, 2019)

Kramsch C. Language and Culture. Oxford: Oxford Introduction to Language Study Series, 1998.

Risager K. and Chapelle C. A. Culture in Textbook Analysis and Evaluation// In C. A. Chapelle (Ed.). The Encyclopedia of Applied Linguistics. Oxford: John Wiley and Sons, Inc., 2013. Pp. 1620-1625. URL: https://lib.dr.iastate.edu/engl_pubs/205 (Accessed: 26 February, 2018).

Risager K. Analyzing Culture in Learning Materials. Spogforum, no. 59, 2014, pp. 78-86. URL: https://unipress.dk/media/3583814/sprogforum_59_risager.pdf(Accessed: 25 February, 2019).

Sandorova Z (2014). Content Analysis as a Research Method in Investigating the Cultural Components in Foreign Language Textbooks. // Journal of Language and Cultural Education, 2(1). URL: http://files.jolace.webnode.sk/200000048-8143a82403/Jolace-2014-1-5.pdf (Accessed: 26 February, 2019).

Хара К. Сан-Фурансисуко хэйва дзёяку-но монтэн (Белые пятна Сан-Францизского мирного договора). Хиросима: Хэйсуйся.

Yoshida Yasuo, Teramura Hideo, Kuratani Naoomi, et. al. Japanese for Today, 1973, Gakken Co., LTD. 